\title{
Taloustietoa koulutuksesta
}

Vaherva, Tapio \& Juva, Simo 1985. Koulutuksen talous. Helsinki: Kustannusosakeyhtiö Tammi. $345 \mathrm{~s}$.

Kaikki tietävät, että koulutusmenot kasvavat maassamme vuosi vuodelta. Tämä on yleinen kehityspiirre kaikissa kehittyneissä teollisuusmaissa. Valtiovallan taholta on yritetty asettaa tälle kehitykselle suitsia suuhun. Lähtökohtana on luonnollisesti valtion menojen kurissapitäminen. Kaikesta edellä mainitusta huolimatta on meillä koulutusta tutkittu vain hyvin vähän taloudellisesta näkökulmasta. Tästä syystä kirjan kirjoittajat pyrkivät aluksi perustelemaan valitsemansa koulutukseen talouteen keskittyvän viitekehyksen. He toteavat, että jos koulutuksen alalla esitetään kehittämisvaatimuksia, niin sen nykyisin käytössä olevat voimavarat ja vaikutukset on asetettava avoimesti tarkasteltavaksi. Tämä vaatimus tuntuu kohtuulliselta. Koulutuksen talous on kuitenkin niin monimutkainen juttu, että avoimuuden hyväksyminen ei vielä asiaa paljon auta. Esim. tässä lehdessä on esitelty jonkin verran tilasto- ym. tietoja 
aikuiskasvatuksen menoista. Tällaiset "tosiasiatiedot" jäävät kuitenkin usein ikäänkuin ilmaan, kun kukaan ei oikein tiedä, millä mittapuulla menoja tulisi mitata ja mihin niitä tulisi verrata. Koulutuksen taloudellinen tutkimus ja suunnittelu tarvitsevat tuekseen teoriaa, jonka avulla tätä "faktamassaa" voidaan jäsentää, analysoida ja arvioida. Kuten asianharrastajat tietävät on ulkomailla julkaistu lukuisia kasvatuksen taloutta ja inhimillistä pääomaa koskevia kirjoja (ks. Blaug 1978). Niissä tarkastellaan yleensä koulutuksen taloutta vain jostakin tietystä näkökulmasta, joten kokonaiskuvan saaminen tämän alueen teoreettisista lähtökohdista ja tutkimuksista ei ole helppoa. Vahervan ja Juvan kirjan hyvänä puolena on se, että siinä on asioita pyritty lähestymään laajasta kokonaisvaltaisesta näkökulmasta ja liittämään erilaiset teoria- ja tutkimussuuntaukset kokonaisuuden osiksi. Kirjassa on esitetty myös jonkin verran koulutuksen taloustieteen historiallista kehitystä. Näin lukija saa kuvan tällä alalla tapahtuneesta kehityksestä ja eri koulukunnista.

Kirja on laadittu siten, että sekä tutkijat että käytännön koulutussuunnittelijat löytävät siitä helposti itseään kiinnostavat asiat. Kirjassa on pyritty yhdistämään koulutussuunnittelun eri lähestymistavat koulutuksen taloustieteellisiin teorioihin ja tässä on myös melko hyvin onnistuttu. Siinä käsitellään laajasti myös koulutuksen vaikuttavuutta.

Tämä osa perustuu Vahervan (1983) aikaisempaan julkaisuun "Koulutuksen vaikuttavuus", mutta aikaisempaa tekstiä on muokattu tähän yhteyteen sopivaksi. Kirjasta käy selkeästi ilmi, miten monitahoinen ja vaikea problematiikka sisältyy koulutuksen taloudellisten ym. vaikutusten tutkimiseen.

Kirjassa esitetään käyttö- kelpoisen tuntuinen koulutuksen taloudellisten vaikutusten tutkimuskehikko, jossa on eroteltu analyysitasot ja analyysin kohteet toisistaan. Sen avulla on mahdollista jäsentää koulutuksen talouden tutkimusaluetta. Analyysitasoina tuodaan esiin makrotaso (yhteiskunta), mesotaso (yritys, tai ehkä yleisemmin voitaisiin puhua organisaatiotasosta) ja mikrotaso (yksilö). Näiden tasojen erottaminen on teoreettisesti tärkeätä, koska vain tiedostamalla se, millä tasolla tutkimuksessa liikutaan, antaa mahdollisuuden tutkimusotteen syventämiseen. Erityisen mielenkiintoinen kysymys on tietysti näiden tasojen keskinäisten suhteiden analysointi. Tätä ei kuitenkaan kirjassa pohdita. Analyysin kohteina mainitaan panokset (resurssit), prosessi (koulutus), tuotokset (suoritteet) ja vaikutukset (hyödyt). Ristiintaulukoimalla analyysitasot ja -kohteet on saatu koulutusekonominen tutkimuskehikko (s. 180), jonka avulla on mahdollista jäsentää alan tutkimussuuntauksia ja tehtyjä tutkimuksia. Kehikkoa olisi voitu hyödyntää tehokkaammin kirjaa laadittaessa, kuin nyt on tehty. Esim. eri analyysitasojen tarkastelu jää ko. luvussa suhteellisen ylimalkaiseksi. Erityisesti mesotason esittely on jäänyt kirjassa pinnalliseksi. Sitä ei tuoda lainkaan esiin esim. sivulla 44 olevassa kaaviossa. Johtuneeko tämä siitä, että yritys/organisaatiotaso ei ole perinteisen kasvatustieteen näkökulmasta kiinnostava tarkastelutaso. Aikuiskasvatuksessa se on joka tapauksessa keskeinen ongelma-alue. Taloudellisesti suuntautuneet organisaatiotutkijat ovat kirjoittaneet tästä problematiikasta joitakin ansiokkaita esityksiä (ks. esim. Mincer 1971; Brinley \& Moxham \& Jones 1969; Oatey 1970; Flamholtz \& Lacey 1981). Tämä analyysitaso on jäänyt kuitenkin aikuiskasvatuksen tutkijoilta lähes huomiotta joten ei ole ihme, että yleisem- mästä näkökulmasta asiaa tarkastelevat kirjoittajat eivät kiinnitä siihen juuri huomiota. On positiivista, että kirjan tekijät ovat joka tapauksessa viitanneet tähän koulutuksen taloustieteen vähemmälle tarkastelulle jääneeseen tasoon. Sen ongelmien luulisi kiinnostavan erityisesti yritysten koulutustoiminnasta vastuussa olevia ja tietysti myös työelämän koulutuksen tutkijoita.

Kirjan 6. luvussa esitellään koulutuksen rahoitusta Suomessa. Tämä luku sisältää paljon koulutusaloittaista yksityiskohtaista faktatietoa valtion ja kunnan koulutusmenoista. Painopiste on koulujärjestelmän menojen esittelyssä. Aikuiskasvatuksen kustannukset on esitelty pintapuolisesti ja osin niin, että alan rahoituksesta voi saada jopa väärän kuvan. Tässä olisi toivonut kirjoittajilta hieman perinpohjaisempaa otetta, sillä vaikka aikuiskasvatuksen kustannuksista ja rahoituksesta ei ole kaikilta osin saatavissa systemaattista tietoa, niin eräiltä alueilta tietojen kerääminen olisi ollut helppoa. Näin on esim. vapaan sivistystyön työmuotojen sekä ammattikasvatushallituksen harjoittaman työllisyys- ja ammattikurssitoiminnan osalta. Vapaan sivistystyön osalta valtionapujärjestelmää esitellään kirjassa vain kansalais- ja työväenopistojen osalta ja näistäkin mainitaan vain valtionavun prosentuaalinen määrä. Minkäänlaisia tietoja kansalaisopistojen, kansanopistojen, opintokeskusten ja sivistysjärjestöjen rahoituksesta kirja ei sisällä. Tämä on valitettava puute. Kirja ei sisällä myöskään tietoja yksityisen elinkeinoelämän koulutuksesta, mutta tämä on ymmärrettävää, koska näitä tietoja ei ole systemaattisesti kerätty.

Eräs aikuiskasvattajia kiinnostava yksityiskohta sisältyy taulukkoon (s. 278), jossa esitellään opetusministeriön me- 
nokehitystä. Siitä ilmenee, että valtiovarainministeriön toimintasuunnitelman mukaan aikuiskasvatuksen suhteellinen osuus tulee selvästi laskemaan tulevaisuudessa. Kun aikuiskasvatuksen osuus oli opetusministeriön menoista vuonna 1983 noin $10 \%$ :a, niin suunnitelmien mukaan se on vuonna 1988 vain noin $8 \%$ :a. On vaikea ymmärtää, mihin tällaiset suunnitelmat perustuvat, kun valtiovarainministeriö on periaatepäätöksessään esittänyt, että aikuiskasvatuksen kehittäminen on tärkeää jatkuvan kasvatuksen järjestelmän toteuttamiseksi.

Kirjan viimeinen luku jää jotenkin irralliseksi, vaikka se sisältääkin tärkeätä taloudellista perustietoa. Suppeamman, taloudellisen kehityksen päälinjat paremmin hahmottavan esityksen laatiminen olisi ollut ilmeisesti paremmin paikallaan.

Vielä muutama lisähuomautus. Kirjan alussa siteerataan presidentti Mauno Koiviston Kasvatusopillisessa $\mathrm{Ai}$ kakauskirjassa vuonna 1959 ollutta artikkelia "Opin tuottavuus'. Kaikki kunnia Koivistolle, mutta tässä yhteydessä olisi ollut paikallaan mainita myös Olavi Niitamo, jonka tutkimuksen ja kirjoitusten perusteella meillä alettiin kiinnittää huomiota koulutuksen taloudellisiin vaikutuksiin. - Kirjan lähdeluettelosta on jäänyt pois joitakin sellaisia teoksia, joihin tekstissä viitataan. Tosin nämä julkaisut ovat ehkä löydettävissä tekstissä annettujen tietojen perusteella. Lieneekö painovirhe vai mikä, mutta Randall Collinsista on tullut jostain syystä Rannald.

Kaiken kaikkiaan Vahervan ja Juvan kirjaa on pidettävä puutteistaan huolimatta tärkeänä lisänä kasvatusalan kirjallisuuteen. Sen merkittävin anti lienee se, että siinä käsitellään kokonaisvaltaisesti koulutuksen taloustieteellisiä kysymyksiä ja ne yhdistetään perinteisiin kasvatussosi- ologisiin teorioihin ja käytännön koulutussuunnitteluun. On kuitenkin todettava, etä kirjasta jää lukijalle hiukan hajanainen ja jäsentymätön kokonaiskuva. Tämä johtuu ilmeisesti siitä, että kirjoittajat ovat lähinnä koostaneet aikaisempia omia tekstejään ja muiden tekstejä ilman kokonaisuutta ohjaavaa punaista lankaa. Kirjaa tiivistämällä ja karsimalla olisi siitä saanut selkeämmän ja paremmin oppikirjaksi sopivan. Kirja helpottaa kuitenkin varmasti yliopisto-opiskelijoiden perehtymistä koulutuksen taloudellisiin ongelmiin. Siitä on apua myös käytännön koulutussuunnittelijoille sekä muille koulutuksen taloudesta ja vaikuttavuudesta kiinnostuneille.

Jukka Tuomisto

\section{Lähteet}

Blaug, M. 1978. Economics of education. A selected annotated bibliography. Third edition. Oxford: Pergamon Press.

Brinley, Thomas \& Moxham, John \& Jones, J. G. 1969. A cost-benefit analysis of industrial training. British Journal of Industrial Relations. Vol. 7, No 2. pp. 231-264.

Flamholtz, Eric \& Lacey, John 1981. The implications of the economic theory of human capital for personnel management. Personnel Review vol. 10, No. 1. 30-40.

Mincer, J. 1962. On the job training: cost, returns and some implications. Journal of political economy. October. pp. $50-73$.

Niitamo, Olavi 1958. Tuottavuuden kehitys Suomen teollisuudessa vuosina 1925-1952. Kansantaloudellisia tutkimuksia XX. Helsinki.
Oatey, Michael 1970. The economics of training with respect to the firm. British journal of industrial relations. Vol. 8, No. 1. pp. $1-21$.

Vaherva, Tapio 1983. Koulutuksen vaikuttavuus. Käsiteanalyyttista tarkastelua ja viitekehyksen hahmottelua. Jyväskylän yliopisto. Kasvatustieteen laitoksen julkaisuja A 1.

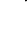

